\title{
Potted plants can remove the pollutant nitrogen dioxide indoors
}

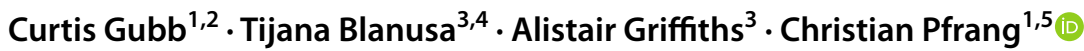

Received: 1 November 2021 / Accepted: 5 February 2022 / Published online: 17 February 2022

(c) The Author(s) 2022

\begin{abstract}
Nitrogen dioxide $\left(\mathrm{NO}_{2}\right)$ is a significant pollutant in both outdoor and indoor environments with exposure linked to serious respiratory illnesses, decreased lung function and airway inflammation. Here, we investigate whether potted plants can contribute as a simple and cost-effective indoor air pollution mitigation technique. Our study investigates the ability of the combination of the three plant species Spathiphyllum wallisii 'Verdi', Dracaena fragrans 'Golden Coast' and Zamioculcas zamiifolia with two different growing media to remove in situ concentrations ( $100 \mathrm{ppb})$ of $\mathrm{NO}_{2}$ in real-time at two typical indoor light levels $(0$ and $500 \mathrm{~lx})$ and in 'wet' and 'dry' growing media conditions. All studied 'growing medium-plant systems' were able to reduce $\mathrm{NO}_{2}$ concentrations representative of a polluted urban environment, but to varying degrees. The greatest $\mathrm{NO}_{2}$ removal measured inside a $150 \mathrm{~L}$ chamber over 1-h period in 'wet' growing media at $\sim 500 \mathrm{~lx}$ was achieved by $D$. fragrans. When accounting for dilution, this would correspond to a removal of up to $3 \mathrm{ppb} \mathrm{NO}_{2}$ per $\mathrm{m}^{2}$ of leaf area over the 1-h test period and $0.62 \mathrm{ppb}$ per potted plant over the same period when modelled for a small office $\left(15 \mathrm{~m}^{3}\right)$ in a highly polluted environment. Depending on building ventilation rates and $\mathrm{NO}_{2}$ concentration gradients at the indoor-outdoor interface that will vary massively between polluted urban and rural locations, potted plants offer clear potential to improve indoor air quality - in particular in confined indoor spaces that are poorly ventilated and/or located in highly polluted areas.
\end{abstract}

Keywords Indoor air quality $\cdot$ Indoor plants $\cdot$ Nitrogen dioxide $\cdot$ Pollutants $\cdot$ Potted plants

\section{Introduction}

\section{Nitrogen oxides $\left(\mathrm{NO}_{x}\right)$ in urban environments}

Nitrogen oxides $\left(\mathrm{NO}_{\mathrm{x}}\right)$ have been shown to react to produce ground level ozone, increase susceptibility to ill health, particularly respiratory infections and also affect soil chemistry (DEFRA 2019). Within the UK, 34\% of the $\mathrm{NO}_{\mathrm{x}}$ is produced

Christian Pfrang

c.pfrang@bham.ac.uk

1 School of Geography, Earth and Environmental Sciences, University of Birmingham, Edgbaston, Birmingham B15 2TT, UK

2 Present Address: Cundall, One Carter Lane, London EC4V 5ER, UK

3 Science and Collections Department, Royal Horticultural Society, Garden Wisley, GU23 6QB Woking, UK

4 School of Agriculture, Policy and Development, University of Reading, Reading RG6 6AS, UK

5 Department of Meteorology, University of Reading, Whiteknights Road, Reading RG6 6BG, UK by road transport (DEFRA 2019). The most noxious component of $\mathrm{NO}_{\mathrm{X}}$ is the pollutant nitrogen dioxide $\left(\mathrm{NO}_{2}\right)$ (WHO 2010). The UK government has set aside $£ 255$ million in the form of 'the $\mathrm{NO}_{2}$ plan', specifically implementing mitigation measures to reduce roadside emissions such as bus retrofits, clean air zones, traffic signal improvements and the phase out of diesel cars by 2040 (DEFRA 2017, 2019); as a pollutant, $\mathrm{NO}_{2}$ also infiltrates indoor environments (WHO 2010).

\section{Nitrogen dioxide $\left(\mathrm{NO}_{2}\right)$ indoors and the associated health impacts}

Indoor concentrations are a function of both indoor and outdoor sources, where elevated outdoor concentrations (e.g. in cities with a greater density of traffic) will inevitably produce elevated indoor concentrations (WHO 2010). Building's proximity to roads or the presence of an attached garage shown to be the largest factor influencing indoor concentrations (Nakai et al. 1995; Janssen et al. 2001; Kodama et al. 2002). Additionally, important indoor sources of $\mathrm{NO}_{2}$ are combustion processes (i.e. from heating appliances, fireplaces and stoves). Indoor concentrations often exceed those 
outdoors because of the presence of these additional indoor sources (Kattan et al. 2007).

The World Health Organisation (WHO), EU Commission and the Department for Environment, Food and Rural Affairs (DEFRA) all set a chronic $\mathrm{NO}_{2}$ health guideline of $40 \mu \mathrm{g} \mathrm{m}^{-3}$ (21 ppb)—aiming to prevent respiratory illnesses and decreases in lung function, the main symptoms of longterm exposure (especially in children) (Hasselblad et al. 1992; Koistinen et al. 2008) — and an acute health guideline of $200 \mu \mathrm{g} \mathrm{m}^{-3}$ (105 ppb) appropriate for both indoor and outdoor environments. However, it has been suggested that the $<40 \mu \mathrm{g} \mathrm{m}^{-3}$ chronic guideline is unlikely to be achievable everywhere, especially in areas with a high density of traffic (Koistinen et al. 2008). Acute exposures to high concentrations of $\mathrm{NO}_{2}$ significantly affect vulnerable groups, e.g. asthmatics, causing minor changes in pulmonary function (at $560 \mu \mathrm{g} \mathrm{m}^{-3}$ for two and a half hours) and increased airway reactivity (at $500 \mu \mathrm{g} \mathrm{m}^{-3}$ ) (Tunnicliffe 1994; Strand et al. 1998; Niimi et al. 2003). Additionally, acute exposures have been associated with airway inflammation in both healthy and asthmatic study participants (DEFRA 2019; Ezratty et al. 2014).

The EU-commissioned INDEX report collected data on mean $\mathrm{NO}_{2}$ concentrations across Europe pre-2004 and found indoor concentrations to be in the range of 13-62 $\mu \mathrm{g} \mathrm{m}^{-3}$ but, in homes with gas cooking and heating equipment, the short-term peak concentrations were measured between 180 and $2500 \mu \mathrm{g} \mathrm{m}^{-3}$. The study found that in up to $25 \%$ of homes $\mathrm{NO}_{2}$ levels exceeded $60 \mu \mathrm{g} \mathrm{m}^{-3}$ (1-week average) (Koistinen et al. 2008).

\section{Mitigation methods to reduce indoor $\mathrm{NO}_{2}$ levels}

Reducing the indoor $\mathrm{NO}_{2}$ concentration indoors would likely reduce health issues alongside economic savings—one study estimated savings of $£ 60,000$ per school through a reduction in asthma flare-ups and associated medical costs (based on parents' willingness to pay model, Guerriero et al. 2016). Indoors, a variety of techniques can be utilised to reduce $\mathrm{NO}_{2}$ concentrations; these include filtration, designing ventilation systems to provide sufficient fresh air and appropriate fans and indoor ventilation for combustion systems. These all require ongoing maintenance and often large initial costs for installation. It should be noted that out of these approaches only filtration can reduce the local indoor pollutant levels to below the outdoor concentrations: ventilation systems will simply lead to an equilibration of indoor and outdoor pollutant levels which only improves indoor air quality if there is a significant concentration gradient with initially higher indoor pollution. Established filtration systems for removal of $\mathrm{NO}_{2}$ indoors include high-efficiency particulate air (HEPA) and carbon filters (e.g. Paulin et al. 2014). Our study investigates the feasibility of a simpler approach to remove $\mathrm{NO}_{2}$ from the gas-phase similarly to a filtration system-low-cost potted indoor plants to remove the pollutant indoors and supplement already existing mitigation techniques.

\section{$\mathrm{NO}_{2}$ removal by vegetation}

The ability of vegetation outdoors (i.e. trees/plants) to remove $\mathrm{NO}_{2}$ has been extensively studied (Morikawa et al. 1998; Teklemariam and Sparks 2006; Jim and Chen 2008; Vallano and Sparks 2008; Nowak et al. 2014). Plants have been shown to remove $\mathrm{NO}_{2}$ through the stomata, simultaneously with $\mathrm{CO}_{2}$ or $\mathrm{O}_{2}$, or through absorption by the water present in the leaves-it can therefore be hypothesised that potted plants would do the same, and the water content of plant and growing media would play an important role (Nowak et al. 2014; Gourdji 2018). Moreover, a clear variation between plant type ability to remove $\mathrm{NO}_{2}$ has been previously measured in a study looking at 217 different plant taxa (including indoor plant species, albeit from dry leaf analysis post-fumigation not in situ, Morikawa et al. 1998). Additionally, it has been suggested that plants with elevated leaf ascorbate concentrations are able to remove more $\mathrm{NO}_{2}$ (Teklemariam and Sparks 2006). It can therefore also be hypothesised that different types of cultivated potted plants will remove $\mathrm{NO}_{2}$ at different rates.

The uptake of $\mathrm{NO}_{2}$ by plants has previously shown to be concentration-dependent; thus, testing at an appropriate guideline concentration is important (Hu and Sun 2010). Additionally, as $\mathrm{NO}_{2}$ is removed via the plant stomatal pathway, it can be assumed-as with $\mathrm{CO}_{2}$ (Gubb et al. 2018, 2019) - that the light levels will influence $\mathrm{NO}_{2}$ removal ability. It has been previously shown that if more UV radiation reaches the plants, a higher $\mathrm{NO}_{2}$ removal is measured (Teklemariam and Sparks 2006; Gourdji 2018). This study will therefore investigate the impact of two light levels on a plants' ability to remove $\mathrm{NO}_{2}$.

Morikawa et al. (1998) investigated the ability of 217 plant taxa to assimilate ${ }^{15} \mathrm{~N}$ labelled $\mathrm{NO}_{2}$ via leaf fumigation and dry leaf analysis. This included several indoor plant species such as Spathiphyllum spp. And Dracaena sanderiana - both possessing a removal ability at the lower end of their respective families. The study found uptake of $\mathrm{NO}_{2}-\mathrm{N}$ content to differ as much as 657 -fold between all the studied taxa, 62-fold within a particular family (Theaceae) and 26-fold within a species (Solidago altissima). Additionally, the authors suggest that the metabolic pathway of $\mathrm{NO}_{2}-\mathrm{N}$ differs among different plant types (Morikawa et al. 1998).

Pettit et al. (2019) recently reported the removal of $\mathrm{NO}_{2}$, $\mathrm{NO}_{\mathrm{X}}$ and $\mathrm{O}_{3}$ via an active green wall in a closed loop flow reactor. The authors tested Spathiphyllum wallisii and Syngonium podophyllum for their ability to remove $\mathrm{NO}_{2}$ at ambient $70 \mathrm{ppb}\left(134 \mathrm{\mu g} \mathrm{m}^{-3}\right)$ and elevated concentrations 
$6656 \mathrm{ppb}\left(12,730 \mu \mathrm{g} \mathrm{m}^{-3}\right)$ at an average photosynthetic flux density of $9.95 \mu \mathrm{mol} \mathrm{m} \mathrm{m}^{-2} \mathrm{~s}^{-1}(\sim 740 \mathrm{~lx})$. The results suggested that at ambient $\mathrm{NO}_{2}$ concentrations and high indoor light levels both plant types were able to remove $\mathrm{NO}_{2}$, with a Clean Air Delivery Rate (CADR) of 79.92 and $87.84 \mathrm{~m}^{3} \mathrm{~h}$ ${ }^{-1} \mathrm{~m}^{-3}$ of biofilter substrate, respectively. The authors, however, did not investigate how humidity inside the closed reactor-which would have risen sharply due to the presence of a plant-may have affected the sensors' ability to accurately measure concentrations. Additionally, the light level and 'elevated concentrations' for the indoor measurements were far exceeding what you would normally find indoors, likely elevating the removal ability of the plants above what could be observed in real indoor environments. Pettit et al. have recently applied the systems tested successfully for botanical biofiltration both for reduction of wildfire-induced $\mathrm{NO}_{2}, \mathrm{O}_{3}$ and $\mathrm{PM}_{2.5}$ (Pettit et al. 2020), and most recently of roadside air pollution (Pettit et al. 2021).

Our research investigates the ability of three indoor potted plant species to remove, in real-time, an in situ concentration of $100 \mathrm{ppb} \mathrm{NO}$ (chronic WHO guideline) on a whole plant/growing media scale with the substrate moisture content (SMC) being 'dry' (SMC $\left.<20 \%, 0.2 \mathrm{~m}^{3} \mathrm{~m}^{-3}\right)$ and 'wet' (SMC $\left.>30 \%, 0.3 \mathrm{~m}^{3} \mathrm{~m}^{-3}\right)$ and at 'typical' $(\sim 500 \mathrm{~lx}$, photosynthetically active radiation, PAR, 15 $\mu \mathrm{mol} \mathrm{m}^{-2} \mathrm{~s}^{-1}$ ) and 'no' (0 lx) indoor light. 0 lx was chosen to investigate taxa's $\mathrm{NO}_{2}$ removal ability in the dark (measured at night), and $\sim 500 \mathrm{~lx}$ was chosen to represent typical office conditions. The effect of the growing media was investigated in further detail once a potentially significant contribution was identified in initial tests.

\section{Material and methods}

\section{Plant material}

Three common houseplant taxa (Dracaena fragrans 'Golden Coast', Spathiphyllum wallisii 'Verdi' and Zamioculcas zamiifolia) were selected for this study. They represented a range of leaf types, physiology (succulent and herbaceous) and plant sizes (Table 1). Plants were maintained in a peatfree growing medium (Sylvamix, 6:2:2 sylvafibre: growbark pine: coir; Melcourt, Tetbury, Gloucestershire, UK) in $3 \mathrm{~L}$ containers (19 cm wide at the top and $15 \mathrm{~cm}$ tall, with 227 $\mathrm{cm}^{2}$ of exposed substrate surface area), with a slow-release fertiliser feed (Osmocote, Marysville, OH, USA). Selected potted plants were purchased one year prior to the study. Within the taxon, plant height and stature were uniform (data not shown). Prior to experimentation (for $>160$ days), plants were kept at room temperatures $\left(21-22^{\circ} \mathrm{C}\right)$ and 'typical' light levels ( $500 \mathrm{~lx})$ in an indoor office environment within the School of Geography, Earth and Environmental Sciences, at the University of Birmingham (UK).

\section{Growing media-only experiments}

For the growing media only experiments (the NO2 chamber experiments-comparison between two different growing media section), the growing media selected were Melcourt Sylvamix medium (6:2:2 sylvafibre: growbark pine: coir; Melcourt, Tetbury, Gloucestershire, UK) and Wyevale Multipurpose Compost (58\% peat; $42 \%$ green compost/coir, exact ratios not disclosed, Wyevale, Brentford, Middlesex, UK). From now on, it is referred to as Sylvamix and Wyevale, respectively.

\section{$\mathrm{NO}_{2}$ chamber experiments}

The experimental setup (Fig. 1A) consisted of a $\sim 150 \mathrm{~L}$ $\left(45 \times 45 \times 75 \mathrm{~cm}, 0.15 \mathrm{~m}^{3}\right)$ Perspex chamber (custom-built by The Plastic People, Leeds, West Yorkshire, UK) connected to a 1000 ppm $\mathrm{NO}_{2}$ in air cylinder (>99\% purity; Speciality Gases, West Bromwich, West Midlands, U.K) with a combination of PTFE tubing ( $1 / 4$ inch outer diameter; Sigma Aldrich, UK) and Ultratorr fittings (Swagelok London, UK). Enclosed inside the Perspex chamber was an electrochemical $\mathrm{NO}_{2}$ sensor (Alphasense, Great Notley, Essex, UK; Fig. 1B) connected via a Raspberry Pi stack with temperature and relative humidity sensor (South Coast Science, Brighton, East Sussex, UK) and a 12 V DC brushless fan (RS Components, Corby, Northants, UK). The chamber was placed in a ventilated laboratory (at the School of Biosciences, University of Birmingham) with a mixture of natural and room lights. The external $\mathrm{RH} /$ temperature surrounding the chamber was monitored with a calibrated (20-90\% $\mathrm{RH} \pm 3 \%, 0-40{ }^{\circ} \mathrm{C} \pm 0.25^{\circ} \mathrm{C}$ ) Tinytag $\mathrm{RH} /$ temperature logger (Gemini Data Loggers, Chichester, West Sussex, UK).

Table 1 Characteristics of the indoor plant taxa chosen for experiments. Leaf area $(n=5)$ and plant height $(n=5)$ are means \pm SEM. Latin (botanical) name is given in italic followed by cultivar, where applicable

\begin{tabular}{lllll}
\hline Taxa & Family & Metabolism & Leaf area $\left(\mathrm{cm}^{2}\right)$ & Plant height $(\mathrm{cm})$ \\
\hline Dracaena fragrans 'Golden Coast' & Asparagaceae & C3 & $3081 \pm 72$ & $70 \pm 1$ \\
Spathiphyllum wallisii 'Verdi' & Araceae & C3 & $5013 \pm 220$ & $43 \pm 1$ \\
Zamioculcas zamiifolia & Araceae & CAM & $2147 \pm 249$ & $77 \pm 1$ \\
\hline
\end{tabular}


Fig. 1 Image of the experimental setup (A) and the electrochemical $\mathrm{NO}_{2}$ sensor $(\mathbf{B})$

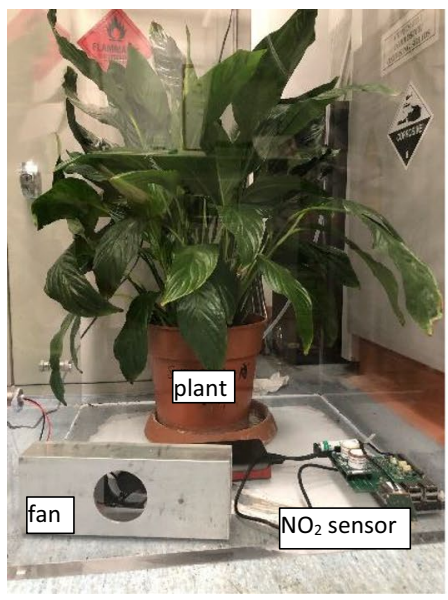

A

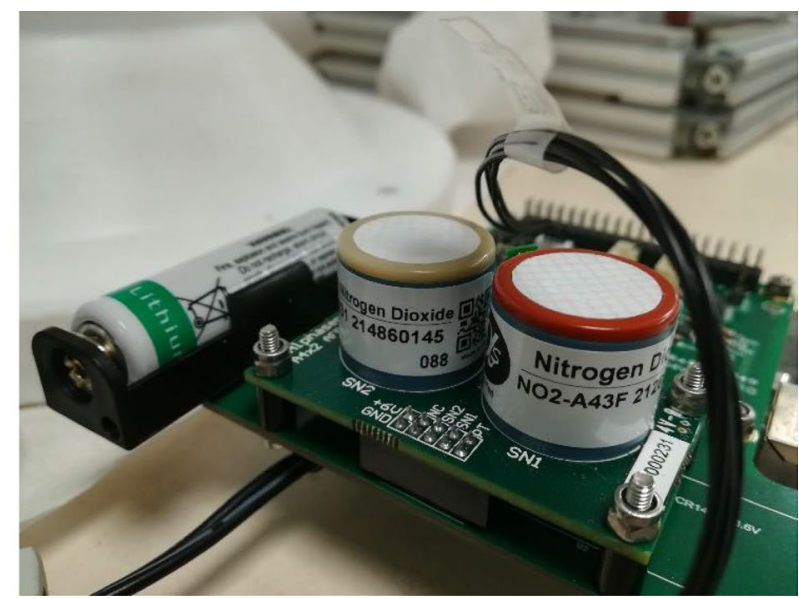

B
Inside the chamber, 'no' light $(01 \mathrm{~lx})$ was achieved by undertaking experiments at night; 'typical' light levels $(\sim 500 \mathrm{~lx})$ were achieved in the usual lighting conditions of the experimental room-all light levels were measured prior to the experiment commencing with a calibrated light sensor (Professional Light Meter, Brannan, Cumbria, UK).

Measurements of the ability of different studied plant types to reduce $\mathrm{NO}_{2}$ concentrations of $100 \mathrm{ppb}$ (WHO acute 1-h guideline; WHO 2010) were undertaken on five plants per taxon, in 'typical' light levels and on 'wet' and 'dry' substrate, as well as in 'no light' for 'dry' (generating three experimental 'treatments', Table 2). The treatment 'no light'/ 'dry' was not introduced as it leads to leaf stomatal closure and thus would have been the least effective and impactful set of conditions. It was therefore decided, after preliminary tests and relatively low $\mathrm{NO}_{2}$ removal rates even in the environmentally most favourable conditions there was no need to test this treatment for the current scope of works.

Plant taxa were prepared for experiments with growing media moisture at the container capacity (substrate moisture content $(S M C)>30 \%)$, and plants were thus considered optimally watered on the commencement of each experiment (Vaz Monteiro et al. 2016). To ascertain the growing media moisture, the SMC was measured prior to experimentation for each plant, in two locations per container using a SM300 capacitance-type probe connected to a $\mathrm{HH} 2$ Moisture Meter
(Delta-T Devices, Cambridge, Cambridgeshire, UK; 0-100\% range and an accuracy of $\pm 2.5 \%$ ). Experiments were carried out on one whole 'plant-growing media system' (i.e. potted plant, with uncovered growing media) enclosed inside the Perspex chamber at an initial $\mathrm{NO}_{2}$ concentration of $100 \mathrm{ppb}$ $( \pm 15 \%)$. Experiments were conducted for a duration of $1 \mathrm{~h}$. Leaf area for each species was determined at the end of the experimental period on two representative plants per species using a WinDias Leaf image analysis system (Delta-T devices, Cambridge, UK).

Appropriate control measurements of the studied $\mathrm{NO}_{2}$ concentration were run at both light levels on both the empty chamber and pot with growing media. The number of runs with only growing media and pot mirrored the replication of the number of experiments including plants $(n=5)$. Further control measurements were undertaken to assess the impact of increasing the humidity within the chamber on both the sensor functionality and the concentration of $\mathrm{NO}_{2}$ measured. Any humidity increases (within an empty chamber) were found to have a negligible effect on the $\mathrm{NO}_{2}$ concentration measured by the sensor (data not shown).

The chamber was also analysed for leakage prior, during and after experimentation; $\mathrm{NO}_{2}$ background loss was found to be on average $4.5 \mathrm{ppb}$ over the one-hour test period. All results were corrected for this loss. The $\mathrm{NO}_{2}$ concentrations removed over the one-hour test period (ppb removed after

Table 2 Experimental and environmental parameters for each lighting treatment during experimentation

\begin{tabular}{|c|c|c|c|c|c|c|}
\hline & \multicolumn{2}{|l|}{ 'No' light } & \multicolumn{2}{|c|}{ 'Typical' light wet } & \multicolumn{2}{|c|}{ ‘Typical' light dry } \\
\hline & Ambient & Inside chamber & Ambient & Inside chamber & Ambient & Inside chamber \\
\hline $\mathrm{NO}_{2}(\mathrm{ppb})$ & $<50$ & - & $<50$ & - & $<50$ & - \\
\hline Temperature $\left({ }^{\circ} \mathrm{C}\right)$ & $21-26$ & $23-27$ & $18-24$ & $20-26$ & $23-26$ & $25-28$ \\
\hline $\begin{array}{l}\text { Relative humidity } \\
(\%)\end{array}$ & $29-54$ & $46-86$ & $38-57$ & $48-87$ & $35-57$ & $42-81$ \\
\hline
\end{tabular}


$1 \mathrm{~h}$; see Table 3 ) by each plant taxon were calculated with the data measured/logged directly every six seconds and divided by the leaf area in $\mathrm{m}^{2}$ presented in Table 1 to enable us to calculate $\mathrm{NO}_{2}$ in ppb removed after $1 \mathrm{~h} \mathrm{~m}^{-2}$ (Fig. 2). Clean Air Delivery Rates per plant $\left(C A D R_{p}\right)$ were calculated following Cummings and Waring (2020) and are also presented in Table 3.

\section{Statistical analysis}

The $\mathrm{NO}_{2}$ concentrations were analysed using SPSS (26th Edition). An analysis of variance (ANOVA) was performed to compare means for each measured parameter between different taxa and/or over time. Variance levels were checked for homogeneity, and values were presented as means with associated standard error of the mean (SEM). Post hoc tests of Tukey's 95\% confidence intervals were undertaken for multiple comparisons.

\section{Results}

\section{$\mathrm{NO}_{2}$ chamber experiments-per plant}

\section{Comparison between different plant types within treatment-per plant}

No statistical differences were measured in $\mathrm{NO}_{2}$ removal between different potted plant types in 'no' light, 'wet' growing media ( $p=0.174)$ or 'typical' light 'dry' growing media ( $p=0.191$; Table 3). In 'typical' light under 'wet' growing media conditions however, a statistically significant difference in $\mathrm{NO}_{2}$ removal was measured between Dracaena fragrans 'Golden Coast' and bare growing media (with Dracaena removing significantly more, 62 vs. 44 ppb removed after $1 \mathrm{~h}$, respectively; $p=0.03$; Table 3 ).

Table 3 Mean $\mathrm{NO}_{2}$ removal per potted plant (ppb removed after $1 \mathrm{~h})$, from inside the chamber containing $100 \mathrm{ppb}$ at 'no' $(0 \mathrm{~lx})$ and 'typical' ( 500 lx) indoor light in 'wet' (SMC> 30\%, $\left.0.3 \mathrm{~m}^{3} \mathrm{~m}^{-3}\right)$ and 'dry' (SMC $\left.<20 \%, 0.2 \mathrm{~m}^{3} \mathrm{~m}^{-3}\right)$ conditions. Data are a mean of

\section{Comparison between treatments within the same plant} type-per plant

Spathiphyllum wallisii removed similar concentrations of $\mathrm{NO}_{2}$ in all three environments tested. This was also the case for bare growing media and Dracaena fragrans 'Golden Coast' ( $p=0.802,0.109$, and 0.508, respectively; Table 3). However, statistical differences were measured for Zamioculcas zamiifolia between the treatments 'no' light 'wet' and 'typical' light 'wet' (where light significantly increased the removal of $\mathrm{NO}_{2}$ - from 47 to $58 \mathrm{ppb}$ removed after $1 \mathrm{~h}$, respectively; $p=0.03$; Table 3 ).

\section{Clean Air Delivery Rates-per plant $\left(\mathrm{CADR}_{\mathrm{p}}\right)$}

We calculated Clean Air Delivery Rates per plant $\left(C A D R_{p}\right)$ following Cummings and Waring (2020) for all of the studied taxa. $C A D R_{p}$ were found to range from 0.095 to $0.145 \mathrm{~m}^{3} \mathrm{~h}^{-1}$ plant $^{-1}$ (see Table 3 ) with the values for the bare growing media ranging from 0.082 to $0.101 \mathrm{~m}^{3} \mathrm{~h}^{-1}$ per pot.

\section{$\mathrm{NO}_{2}$ chamber experiments-per $\mathrm{m}^{2}$ of leaf area}

\section{'No' light, wet-per $\mathrm{m}^{2}$ of leaf area}

After one hour, statistical differences in $\mathrm{NO}_{2}$ removal were measured between Spathiphyllum wallisii 'Verdi' (115 ppb removed after $1 \mathrm{~h} \mathrm{~m}^{-2}$ ) and both, Dracaena fragrans 'Golden Coast' and Zamioculcas zamiifolia (185 and $218 \mathrm{ppb}$ removed after $1 \mathrm{~h} \mathrm{~m}^{-2}$, respectively; $p<0.01$; Fig. 2). However, no statistical differences were measured between Dracaena fragrans 'Golden Coast' and Zamioculcas zamiifolia ( $p=0.08$; Fig. 2).

five plants per plant type \pm SEM. Clean Air Delivery Rates per plant $\left(C A D R_{p}\right)$ calculated following Cummings and Waring (2020) are presented in square brackets. Different letters next to the means within a column indicate statistically significant differences

\begin{tabular}{|c|c|c|c|}
\hline & \multicolumn{3}{|c|}{$\begin{array}{l}\mathrm{NO}_{2}(\mathrm{ppb} \text { removed after } 1 \mathrm{~h}) \\
{\left[C A D R_{p}\left(\mathrm{~m}^{3} \mathrm{~h}^{-1} \text { plant }^{-1}\right)\right]}\end{array}$} \\
\hline & 'No' wet & 'Typical' wet & 'Typical' dry \\
\hline Dracaena fragrans 'Golden Coast' & $\begin{array}{l}57 \pm 1 \mathrm{a} \\
{[0.127]}\end{array}$ & $\begin{array}{l}62 \pm 6 \mathrm{a} \\
{[0.145]}\end{array}$ & $\begin{array}{l}49 \pm 4 \mathrm{a} \\
{[0.101]}\end{array}$ \\
\hline Spathiphyllum wallisii 'Verdi' & $\begin{array}{l}58 \pm 6 \mathrm{a} \\
{[0.130]}\end{array}$ & $\begin{array}{l}60 \pm 3 \mathrm{ab} \\
{[0.137]}\end{array}$ & $\begin{array}{l}55 \pm 6 \mathrm{a} \\
{[0.120]}\end{array}$ \\
\hline Zamioculcas zamiifolia & $\begin{array}{l}47 \pm 2 \mathrm{a} \\
{[0.095]}\end{array}$ & $\begin{array}{l}58 \pm 3 \mathrm{ab} \\
{[0.130]}\end{array}$ & $\begin{array}{l}49 \pm 3 \mathrm{a} \\
{[0.101]}\end{array}$ \\
\hline Bare growing media & $\begin{array}{l}49 \pm 5 \mathrm{a} \\
{[0.101]}\end{array}$ & $\begin{array}{l}44 \pm 4 b \\
{[0.087]}\end{array}$ & $\begin{array}{l}42 \pm 3 \mathrm{a} \\
{[0.082]}\end{array}$ \\
\hline
\end{tabular}


Fig. 2 Mean $\mathrm{NO}_{2}$ removal per $\mathrm{m}^{2}$ of leaf area as a function of time from a concentration of $100 \mathrm{ppb}$ by each plant type under differing environmental conditions per $\mathrm{m}^{2}$ of leaf area over a 1 -h period (see legend). With light level defined as either 'no' (0 lx) or 'typical' $(\sim 500 \mathrm{~lx})$ and substrate moisture content defined as 'wet' $\left(\mathrm{SMC}>30 \%, 0.3 \mathrm{~m}^{3} \mathrm{~m}^{-3}\right)$ or 'dry' (SMC <20\%, $\left.0.2 \mathrm{~m}^{3} \mathrm{~m}^{-3}\right)$. Data are a mean of five plants per plant type - error bars represent SEM

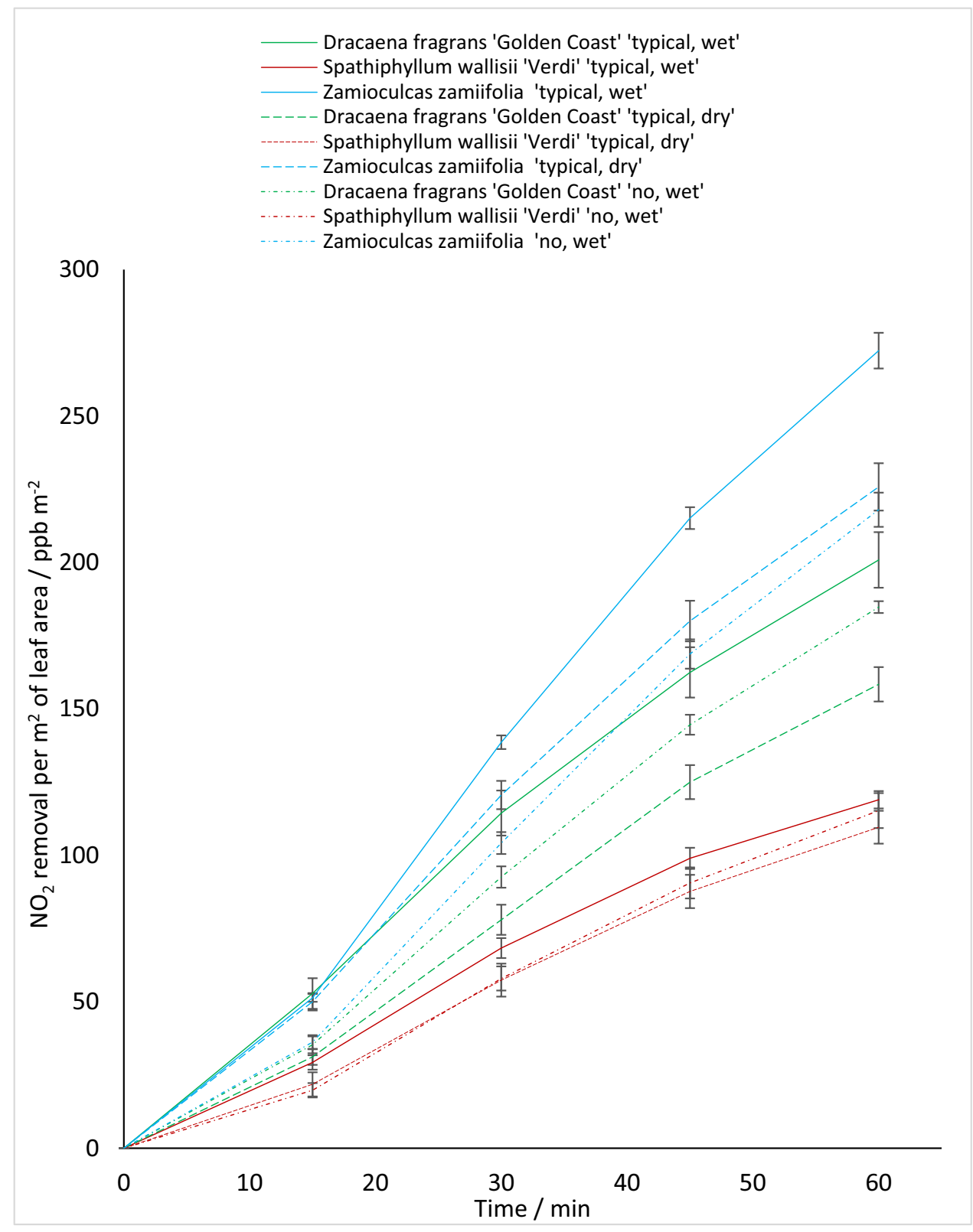

\section{‘Typical' indoor light level, dry—per $\mathrm{m}^{2}$ of leaf area}

After one hour, statistical differences in $\mathrm{NO}_{2}$ were measured between Zamioculcas zamiifolia and both Spathiphyllum wallisii 'Verdi' and Dracaena fragrans 'Golden Coast' (226, 110 and $158 \mathrm{ppb}$ removed after $1 \mathrm{~h} \mathrm{~m}^{-2} ; p<0.01$ ). However, no statistical differences were measured between Spathiphyllum wallisii 'Verdi' and Dracaena fragrans 'Golden Coast' $(p=0.06$; Fig. 2).

\section{'Typical' indoor light level, wet—per $\mathrm{m}^{2}$ of leaf area}

After one hour, Zamioculcas zamiifolia removed more than Dracaena fragrans 'Golden Coast' and Spathiphyllum wallisii 'Verdi' (272, 201, and 119 ppb removed after $1 \mathrm{~h} \mathrm{~m}^{-2}$, respectively; $p<0.01$; Fig. 2).

\section{Comparison between treatments within plant type-per $\mathrm{m}^{2}$ of leaf area}

After one hour, a statistical difference in $\mathrm{NO}_{2}$ removal was measured between the treatments of 'typical' light wet and 'typical' light dry for Zamioculcas zamiifolia (272 and $226 \mathrm{ppb}$ removed after $\left.1 \mathrm{~h} \mathrm{~m}^{-2} ; p=0.04\right)$. No other statistical differences were measured between treatments for either Spathiphyllum wallisii 'Verdi' or Dracaena fragrans 'Golden Coast' ( $p=0.8$ and $p=0.1$, respectively; Fig. 2). 


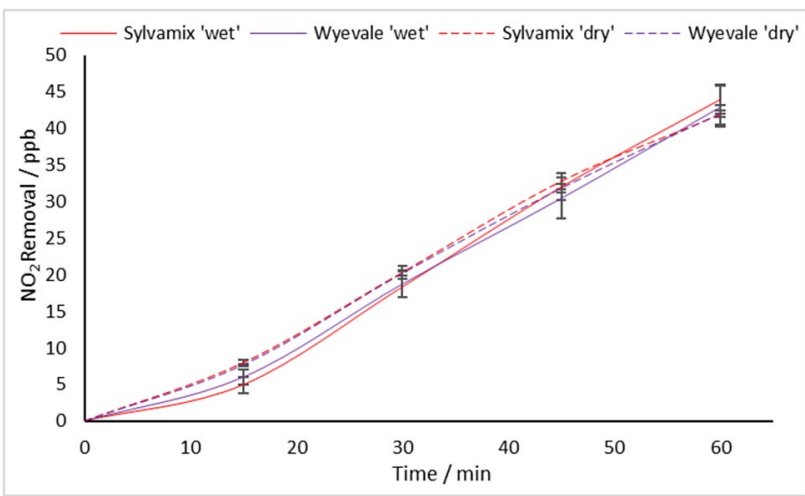

Fig. 3 Mean $\mathrm{NO}_{2}$ removal as a function of time from a concentration of $100 \mathrm{ppb}$ over a 1-h period by Sylvamix and Wyevale in 'wet' $\left(\mathrm{SMC}>30 \%, 0.3 \mathrm{~m}^{3} \mathrm{~m}^{-3}\right)$ and 'dry' $\left(\mathrm{SMC}<20 \%, 0.2 \mathrm{~m}^{3} \mathrm{~m}^{-3}\right)$ substrate moisture conditions at 'typical' $(\sim 5001 \mathrm{~lx})$ light levels. Data are a mean of five growing medias per growing media-error bars represent SEM

\section{$\mathrm{NO}_{2}$ chamber experiments-comparison between two different growing media}

No statistical differences in $\mathrm{NO}_{2}$ removal were measured between any treatments or growing media types at any timepoint ( $15 \mathrm{~min}, p=0.472 ; 30 \mathrm{~min}, p=0.909 ; 45 \mathrm{~min}$, $p=0.972 ; 60 \mathrm{~min}, p=0.966$; Fig. 3).

\section{Using chamber-based results to estimate room-level $\mathrm{NO}_{2}$ exposure}

From the experiments, taking into account volumetric considerations, we are able to estimate the amount of $\mathrm{NO}_{2}$ each taxon may remove per plant and per $\mathrm{m}^{2}$ in a sealed 15 $\mathrm{m}^{3}$ room (the size of the PI's office) containing $100 \mathrm{ppb}-$ assuming there are no additional sources within the room and the $100 \mathrm{ppb}$ is uniformly distributed throughout. It should be noted that this estimation of the maximum impact is not considering natural or mechanical ventilation which is highly variable and may substantially alter the indoor $\mathrm{NO}_{2}$ exposure in particular if there is a significant indoor-outdoor concentration gradient. In typical buildings, the outdoor-toindoor air exchange provides approximately one air change per hour $\left(\sim 1 \mathrm{~h}^{-1}\right)$ (Cummings and Waring 2020).

For natural ventilation, air change rates are incredibly difficult to predict due to uncertainties around wind speed, pressure coefficient, air temperature and ventilation area (Clements-Croome 2005; HM Government 2015). With mechanical ventilation, various guidance bodies specify a minimum air supply criteria in litres per second per person with $U K$ building regulations (Part F) suggesting a minimum of 10/L/s/per person (HM Government 2015).

Taking into account volumetric loading differences (Girman 1992) between the test chamber $\left(0.15 \mathrm{~m}^{3}\right)$ and the small office $\left(15 \mathrm{~m}^{3}\right)$, the rate of $\mathrm{NO}_{2}$ removal is reduced by a factor of 100. Therefore, using measured removal rates (Fig. 2) and reducing by a factor of 100 allows us to derive the removal rate in a small office (Table 4). We therefore estimate that 1 $\mathrm{m}^{2}$ of the highest $\mathrm{NO}_{2}$ removing taxa per $\mathrm{m}^{2}$-Zamioculcas zamiifolia-in optimal environmental conditions, namely 'typical' light and 'wet' growing medium, would reduce a concentration of $100 \mathrm{ppb}$ by $3 \mathrm{ppb}$ after $1 \mathrm{~h}$ (data not shown). Furthermore, the highest removing potted plant (not considering leaf area), namely Dracaena fragrans 'Golden Coast' potted in wet growing media under 'typical' light conditions, was able to reduce a concentration of $100 \mathrm{ppb}$ by $0.62 \mathrm{ppb}$ after $1 \mathrm{~h}$. Results from all plant types under these presumed conditions are presented below, in Table 4.

\section{Discussion}

\section{Interpretation of chamber-based experimental results}

This work investigates the ability of three common indoor potted plants to remove - in real-time, over a period of $1 \mathrm{~h}-$ an in situ concentration of $100 \mathrm{ppb}$ of $\mathrm{NO}_{2}$ from a $150-\mathrm{L}$ chamber. We demonstrate that the studied potted plants are able to remove significant amounts of $\mathrm{NO}_{2}$ under common indoor conditions, i.e. 0 and $500 \mathrm{~lx}$. As per the hypothesis, different taxa were able to remove $\mathrm{NO}_{2}$ at differing ratesper $\mathrm{m}^{2}$ of leaf area (Fig. 2), suggesting different inherent capacities for $\mathrm{NO}_{2}$ removal. However, contrary to the initial hypothesis that water content of the growing media would influence $\mathrm{NO}_{2}$ removal, only one plant type-Zamioculcas zamiifolia - was significantly influenced by this. Additionally, although the growing media significantly contributed to $\mathrm{NO}_{2}$ removal-equal removal within error for the plant species Spathiphyllum wallisii 'Verdi' and Dracaena fragrans 'Golden Coast' - the type of growing medium used (peat or peat free) or its water content made no statistically significant difference to the $\mathrm{NO}_{2}$ removal ability.

Table 4 The derived ability of each studied potted plant to reduce a concentration of $100 \mathrm{ppb}$ inside a $15 \mathrm{~m}^{3}$ room in 'wet' (SMC $>30 \%$, $\left.0.3 \mathrm{~m}^{3} \mathrm{~m}^{-3}\right)$ substrate moisture conditions at 'typical' ( $\left.500 \mathrm{~lx}\right)$ light levels

\begin{tabular}{ll}
\hline & $\begin{array}{l}\mathrm{NO}_{2} \text { (ppb } \\
\text { removed after } \\
1 \mathrm{~h})\end{array}$ \\
& 'Typical' wet \\
\hline Dracaena fragrans 'Golden Coast' & 0.62 \\
Spathiphyllum wallisii 'Verdi' & 0.60 \\
Zamioculcas zamiifolia & 0.58 \\
\hline
\end{tabular}


In terms of removal per plant (ppb removed after $1 \mathrm{~h}$ ), very few statistical differences were measured within or between treatments across all plant types and bare growing medium. This suggests that both the light level and growing media moisture had little effect on the $\mathrm{NO}_{2}$ removal at single plant scale. Moreover, the similarity of removal between bare growing media and potted plants across all treatments suggests that most of the removal is achieved via the growing medium itself. Removal would likely be through breakdown by the microbial activity within the growing media or absorption through moisture contained within the soil-as $\mathrm{NO}_{2}$ is absorbed by water (Dekker et al. 1959). Thus, further investigation and experiments were required (the $\mathrm{NO} 2$ chamber experiments-comparison between two different growing media section).

Investigating another growing medium for its $\mathrm{NO}_{2}$ removal ability was hypothesized to clarify if microorganisms were breaking down/metabolising the pollutant. As different growing media support different microorganisms (Zhang et al. 2013) and possess differing adsorptive properties, it would be expected that variances in removal would be measured. However, no statistical differences in $\mathrm{NO}_{2}$ removal were measured between 'wet', 'dry' or growing media types at any timepoint over the 1-h experiment (Fig. 3). This suggests that in the context of our experiment there either were no differences in microbial communities' composition, no differences in microbial activity or that the contribution of this pathway to $\mathrm{NO}_{2}$ removal is insignificant. Moreover, the fact that no statistical differences were measured between growing media moisture content ('wet' and 'dry', Fig. 3) suggested that moisture absorption of $\mathrm{NO}_{2}$ was also not the primary removal pathway. However, further experiments (data not shown) at very low moisture content $(\mathrm{SMC}<10 \%)$ saw a reduction in removal rate, and it is therefore suggested that even in 'dry' growing media conditions (in a biological and practical horticultural sense, 15-20\%), enough moisture was still present to remove $\mathrm{NO}_{2}$.

In terms of removal per $\mathrm{m}^{2}$ of leaf area, statistical differences were often measured between different plant types for the same light or substrate moisture treatment-confirming that there is an inherent difference between plant types to remove $\mathrm{NO}_{2}$; this aligns with our hypothesis and is supported by previous work (Morikawa et al. 1998). However, when comparing between treatments within the same plant type, statistical differences were only measured for Zamioculcas zamiifolia in 'typical' light between 'wet' and 'dry' growing media. This suggests that neither light—up to $500 \mathrm{~lx}$-nor water content (down to very low SMC, i.e. below $10 \%$ ) had much of an effect on the $\mathrm{NO}_{2}$ removal ability of each taxa, aligning with the per plant removal results. Furthermore, removal experiments investigating growing media alone showed a similar pattern of little change in $\mathrm{NO}_{2}$ removal in response to the change in environmental conditions (Fig. 3). This lends further weight to the 'per plant result' conclusion that the growing medium (and its associated moisture content) is responsible for a large part of the $\mathrm{NO}_{2}$ removal. Whilst the detailed mechanism could not be resolved in our experiments, it appears that even a very small amount of moisture within the substrate appears to be more important for $\mathrm{NO}_{2}$ removal efficiency than any of the other parameters we have investigated here.

\section{Potential implications for room-level $\mathrm{NO}_{2}$ exposure}

Based on our chamber experiments and taking into account volumetric considerations, we have estimated the amount of $\mathrm{NO}_{2}$ each taxon may remove per plant and per $\mathrm{m}^{2}$ of leaf area in a sealed $15 \mathrm{~m}^{3}$ room (the size of the PI's office) containing $100 \mathrm{ppb}$ - assuming there are no additional $\mathrm{NO}_{2}$ sources within the room and the $100 \mathrm{ppb}$ is uniformly distributed throughout. These estimates (see Table 4) suggest that five plants in such a small office could remove approximately $3 \mathrm{ppb}$ of $\mathrm{NO}_{2}$ after $1 \mathrm{~h}$. At first sight, such a removal rate may look relatively low, but it should be noted that the measured $\mathrm{NO}_{2}$ removal occurred in typical light and even dark conditions whilst $\mathrm{NO}_{2}$ exposure peaks tend to appear over short, often rush-hour-related periods (Malley et al. 2018; Engström and Forsberg 2019). It can therefore be expected for any removal to be constant throughout the day or night, even when plants are under mild water deficit—unlike with $\mathrm{CO}_{2}$ where supplementary lighting was required for $\mathrm{CO}_{2}$ uptake to occur (Gubb et al. 2018, 2019). Therefore, plants are able to remove $\mathrm{NO}_{2}$, without additional energy requirements. Furthermore, as plant type seems to have little effect (Table 4) on $\mathrm{NO}_{2}$ removal at the office scale (considering the plant types in this study only), easier-to-maintain plants like Zamioculcas zamiifolia and other succulents would likely be just as effective.

Comparing to our earlier work on the potted plants' ability to remove carbon dioxide $\left(\mathrm{CO}_{2}\right)$ indoors (Gubb et al. 2018, 2019), the fact that removal of $\mathrm{NO}_{2}$ occurs at typical indoor light levels is a significant advantage. Without the need for supplementary lighting, increasing both energy costs and integration difficulties for designers, passive $\mathrm{NO}_{2}$ mitigation via potted plants is a much more viable technique-especially with the built environments push towards net-zero carbon buildings.

Our work is consistent with recent experiments that have suggested that the growing media and the microorganisms within are predominantly involved in the removal of pollutants and plants themselves are only utilised in-directly to maintain and support growing media microorganisms (Irga et al. 2018; Kim et al. 2018).

As both the concentration of $\mathrm{NO}_{2}$ and light levelalbeit, $>5001 \mathrm{x}$-affect the removal ability of plants (Teklemariam and Sparks 2006; Gourdji 2018; Hu and Sun 2010), 
direct comparison to literature is difficult, unless removal with exactly the same conditions were investigated. However, numerous studies have tested outdoor vegetation for $\mathrm{NO}_{2}$ removal, and this study aligns with those (Morikawa et al. 1998; Nowak et al. 2014; Petit et al. 2019) in the fact that all studied plant types were able to remove $\mathrm{NO}_{2}$ to varying degrees at a wide variety of concentrations.

\section{Comparison to alternative approaches to reduce $\mathrm{NO}_{2}$ exposure}

To put our small office estimate of an $\mathrm{NO}_{2}$ removal of $\sim 3 \mathrm{ppb}$ after hour from five potted plants into context, it is useful to compare to alternative approaches that have been taken to reduce $\mathrm{NO}_{2}$ exposure in urban areas. As an example, the Agglomeration of Lausanne-Morges (ALM) in Switzerland has a long-term record of introduction of successful clean air policies and a recent study by Castro et al. (2017) compared to the health benefits resulting from these policies over the decade 2005-2015. They suggested that the $\mathrm{NO}_{2}$ exposure reduction by $2.8 \mathrm{ppb}$ in the ALM region may have lowered the $\mathrm{NO}_{2}$-related deaths by 51 and the life-years lost by 550 years in this 10-year period (Castro et al. 2017). Based on our estimate, five potted plants in each small office may be able to reduce the indoor $\mathrm{NO}_{2}$ exposure for the occupant to a comparable extent (it is worth noting that Castro et al. based their findings on annual average $\mathrm{NO}_{2}$ exposure, so the impact of potted plants in offices on life-years lost will not be as dramatic since most office occupants will not spend nearly $100 \%$ of their time annually in small plant-filled rooms). However, studies of mechanical and natural ventilation systems as well as investigations of the long-term ability of potted plants to retain $\mathrm{NO}_{2}$ are needed to establish how significant the air quality services of potted plants are both in the long-term and in a wide range of real-life conditions. We would also expect that $\mathrm{NO}_{2}$ removal efficiencies of the potted plants are not linear and that they will decrease with decreasing ambient $\mathrm{NO}_{2}$ concentrations.

\section{Potential impact on indoor $\mathrm{NO}_{2}$ levels depending on Clean Air Delivery Rate (CADR), Air Changes per Hour (ACH) and room volume}

The calculated Clean Air Delivery Rates per plant $\left(C A D R_{p}\right)$ presented in Table $3\left(0.095\right.$ to $0.145 \mathrm{~m}^{3} \mathrm{~h}^{-1}$ plant $\left.^{-1}\right)$ are unsurprisingly much lower than the results from the active wall experiments by Pettit et al. (2019), where the CADR was two orders of magnitude higher. Our result was comparable to some of the studies summarised by Cummings and Waring (2020). This recent review paper calculated the CADR from 12 previously published potted plant VOC removal studies (but none investigating $\mathrm{NO}_{2}$ removal). The study found that the distribution of single-plant CADR spanned orders of magnitude, with a median of $0.023 \mathrm{~m}^{3} / \mathrm{h}$ (i.e. 4-5 times lower than what we found). Their median CADR would require the placement of $10-1000$ plants $/ \mathrm{m}^{2}$ of floor area for the combined VOC-removing ability by potted plants to achieve the same removal rate that outdoorto-indoor air exchange already provides in typical buildings $\left(\sim 1 \mathrm{~h}^{-1}\right)$. However, the review fails to take into account differing pollutant toxicities across VOCs, whereby a smaller CADR may still be effective if the pollutant is highly toxic at a relatively low concentration, i.e. $\mathrm{NO}_{2}$.

Additionally, it should be noted that outdoor-to-indoor air exchange for pollutants such as $\mathrm{NO}_{2}$ may also increase the indoor $\mathrm{NO}_{2}$ exposure especially since ventilation rates are likely to be higher during outdoor $\mathrm{NO}_{2}$ peak periods (daytime, particularly during the morning rush-hour period when people tend to arrive at work and thus open doors and potentially windows) than during low $\mathrm{NO}_{2}$ outdoor concentrations (night-time) unless a smart and active ventilation system is in place. In passively ventilated buildings which still represent the vast majority of buildings in the UK, a continuous $\mathrm{NO}_{2}$ removal by potted plants can thus provide indoor air quality services. This can be in addition to exhaust fans or window opening, which remain the most effective way to reduce very high indoor $\mathrm{NO}_{2}$ from indoor gas combustion (Clements-Croome 2005).

To illustrate the impact of varying ventilation rates and room sizes, we have calculated the reduction of indoor $\mathrm{NO}_{2}$ in a range of conditions for Air Changes per Hour ( $A C H)$ of $0.2,1$ and $1 \mathrm{~h}^{-1}$ and room volumes $(V)$ of 15 and 100 $\mathrm{m}^{3}$. The outdoor $\mathrm{NO}_{2}$ mixing ratios $\left(C_{\text {out }}\right)$ were assumed to be either $100 \mathrm{ppb}$ or $20 \mathrm{ppb}$. At steady state and ignoring potential $\mathrm{NO}_{2}$ consumption by gas phase and surface chemistry, the $\mathrm{NO}_{2}$ indoor concentration $\left(C_{\mathrm{in}}\right)$ is assumed to relate to $C_{\text {out }}$, by

$\mathrm{C}_{\text {in }}=\mathrm{ACH} \times \mathrm{C}_{\text {out }} /(\mathrm{ACH}+\mathrm{CADR} / \mathrm{V})$

with $C A D R$ corresponding to $C A D R_{p}$ multiplied by the number of plants in the room. For five plants of our most efficient $\mathrm{NO}_{2}$ removing plant (Dracaena fragrans 'Golden Coast'; $C A D R_{p}=0.145$ in 'typical' wet conditions; see Table 3), we obtained the values presented in Table 5 .

Table 5 clearly illustrates the importance of $\mathrm{ACH}$ : in poorly ventilated areas, the five potted plants show potential to remove significant amounts of $\mathrm{NO}_{2}$ even in larger rooms, but their impact will be limited for areas with ACH of $2 \mathrm{~h}^{-1}$ or higher.

Further experiments measuring the effect of removal over a longer time period should be carried out allowing for determination of how the removal rate may alter. Another important area of future study ought to include the role of growing media/substrates or the use of hydroponic growing systems. 
Table 5 Reduction of indoor $\mathrm{NO}_{2}$ levels $\left(\mathrm{C}_{\mathrm{in}}\right)$ by five potted plants of Dracaena fragrans 'Golden Coast' in a range of conditions calculated from Eq. (1) for two outdoor $\mathrm{NO}_{2}$ levels (20 ppb and $100 \mathrm{ppb}$ ), two room volumes $\left(15 \mathrm{~m}^{3}\right.$ and $\left.100 \mathrm{~m}^{3}\right)$ and three rates of Air Changes per Hour (ACH) of $0.2,1$ or $2 \mathrm{~h}^{-1}$

\begin{tabular}{llll}
\hline & \multicolumn{2}{l}{$C_{\text {in }}(\mathrm{ppb})$} & \\
\cline { 2 - 4 } & ACH: $0.2 \mathrm{~h}^{-1}$ & ACH: $1 \mathrm{~h}^{-1}$ & ACH: $2 \mathrm{~h}^{-1}$ \\
\hline$C_{\text {out }}=100 \mathrm{ppb}$ & & & \\
$V=15 \mathrm{~m}^{3}$ & 80.5 & 95.4 & 97.6 \\
$V=100 \mathrm{~m}^{3}$ & 96.5 & 99.3 & 99.6 \\
$C_{\text {out }}=20 \mathrm{ppb}$ & & & \\
$V=15 \mathrm{~m}^{3}$ & 16.1 & 19.1 & 19.5 \\
$V=100 \mathrm{~m}^{3}$ & 19.3 & 19.9 & 19.9 \\
\hline
\end{tabular}

We do not dispute the notion that future work on green walls (especially 'active' walls) is urgently needed since these yield more effective removal due to an increased leaf area of taxa and increased growing media airflow (Irga et al. 2018). In their study, Pettit et al. (2019) found $\mathrm{NO}_{2}$ removal, i.e. the CADR was measured at 79.92 and $87.84 \mathrm{~m}^{3} \mathrm{~h}^{-1} \mathrm{~m}^{-3}$ of biofilter substrate, respectively-three orders of magnitude greater than the passive removal studies. Other active wall studies investigating VOCs have found similar CADRs (i.e. 28.3 and $18.9 \mathrm{~m}^{3} \mathrm{~h}^{-1} \mathrm{~m}^{-2}$ green wall area, per different plant type) (Torpy et al. 2018). These however require a significantly increased amount of energy, irrigation considerations and thorough maintenance in comparison to simple potted plants and may not be suitable for all environments-albeit whilst providing greater removal (Cummings and Waring 2020). Thus, passive low-tech potted plant $\mathrm{NO}_{2}$ removal should not be overlooked given the wide and immediate availability across the globe and a significant potential to improve indoor air quality (for a review of research on indoor pollutant removal services of houseplants, see Gubb et al. 2020), particularly, in small offices in urban environments without smart, active ventilation systems. For occupants of these offices, a realistic number of potted plants may have comparable health benefits to clean air policies that are obviously crucial to reduce $\mathrm{NO}_{2}$ exposure outdoors.

\section{Conclusion}

This study investigated if a simple set up, with just a potted houseplant, could be effective at passively removing the harmful pollutant $\mathrm{NO}_{2}$. This was carried out by investigating the ability of the combination of the plant species Spathiphyllum wallisii 'Verdi', Dracaena fragrans 'Golden Coast' and Zamioculcas zamiifolia with two different growing media to remove in situ concentrations of $\mathrm{NO}_{2}$ in real-time at two typical indoor light levels and in 'wet' and 'dry' growing media conditions.

All studied growing medium-plant combinations were able to reduce the $\mathrm{NO}_{2}$ concentrations representative of a polluted urban environment, but to varying degrees. Growing medium and/or moisture contained within emerged as a significant pathway of $\mathrm{NO}_{2}$ removal.

The greatest $\mathrm{NO}_{2}$ removal measured in a $150-\mathrm{L}$ chamber over 1-h period corresponded to $272 \mathrm{ppb}$ removed after $1 \mathrm{~h}$ per $\mathrm{m}^{2}$ of leaf area and 58 to $62 \mathrm{ppb}$ per plant over the 1-h period for each of the three plant types in 'wet' growing media at $\sim 5001 \mathrm{~lx}$. This would correspond to a removal of up to $3 \mathrm{ppb}$ per $\mathrm{m}^{2}$ of leaf area after $1 \mathrm{~h}$ and $0.62 \mathrm{ppb}$ per plant after $1 \mathrm{~h}$ in a small office when not considering natural or mechanical ventilation. The studied plant types remove clearly measurable amounts of $\mathrm{NO}_{2}$ passively during the day and night without additional energy requirements (unlike mechanical ventilation or filtration systems), thus adding indoor air quality services and the associated health benefits to the other established building services potted plants provide at minimal cost.

This passive removal approach is unsurprisingly significantly less effective than the deployment of 'active' green walls, highlighting the need for further research in this area. However, these require a significantly increased amount of energy, irrigation considerations and maintenance compared to potted plants. This study demonstrates that simple potted plants will passively remove $\mathrm{NO}_{2}$ under typical indoor conditions. The air quality 'services' delivered by potted plants will also strongly depend on room size and competing removal routes such as building ventilation, as well as on the success of clean air policies aiming to reduce outdoor $\mathrm{NO}_{2}$ peak events that will in turn impact on indoor $\mathrm{NO}_{2}$ exposure.

Acknowledgements This work was supported by the Royal Horticultural Society (RHS) and the Engineering and Physical Sciences Research Council (EPSRC). The authors would also like to thank Dr Louisa Kramer, Dr Leigh Crilley, Weizhang Zhang, Rob Stirling, David Tubbs, Dr Nicholas Davidson and Eimear Orgill for their practical guidance and support.

Author contribution This work was conceptualised by $\mathrm{CP}$ with input from TB and CG. The experiments were carried out by CG with support by $\mathrm{CP}$ and $\mathrm{TB}$. The original draft of the manuscript was written by $\mathrm{CG}$ with input from $\mathrm{CP}$ and $\mathrm{TB}$ and at review stage from AG.

Funding Royal Horticultural Society (RHS) and the Engineering and Physical Sciences Research Council (EPSRC).

Data availability Associated data are available from the corresponding author and also presented in CG's PhD thesis.

Code availability Not applicable. 


\section{Declarations}

Ethics approval Not applicable.

Consent to participate Not applicable.

Consent for publication All authors whose names are present on the title page agreed with the content and that all gave explicit consent to submit.

\section{Conflict of interest Not applicable.}

Open Access This article is licensed under a Creative Commons Attribution 4.0 International License, which permits use, sharing, adaptation, distribution and reproduction in any medium or format, as long as you give appropriate credit to the original author(s) and the source, provide a link to the Creative Commons licence, and indicate if changes were made. The images or other third party material in this article are included in the article's Creative Commons licence, unless indicated otherwise in a credit line to the material. If material is not included in the article's Creative Commons licence and your intended use is not permitted by statutory regulation or exceeds the permitted use, you will need to obtain permission directly from the copyright holder. To view a copy of this licence, visit http://creativecommons.org/licenses/by/4.0/.

\section{References}

Castro A, Künzli N, Götschi T (2017) Health benefits of a reduction of PM10 and $\mathrm{NO}_{2}$ exposure after implementing a clean air plan in the Agglomeration Lausanne-Morges. Int J Hyg Environ Health 220:829-839

Clements-Croome D J (2005) Natural ventilation in non-domestic buildings. In: Application Manual AM10 (Second Edition). Chartered Institution of Building Services Engineers. ISBN 9781903287569

Cummings BE, Waring MS (2020) Potted plants do not improve indoor air quality: a review and analysis of reported VOC removal efficiencies. J Expo Sci Environ Epidemiol 30:253-261

Dekker WA, Snoeck E, Kramers H (1959) The rate of absorption of $\mathrm{NO}_{2}$ in water. Chem Eng Sci 11:61-71

Department for Environment, Food \& Rural Affairs (2017) UK plan for tackling roadside nitrogen dioxide concentrations. Available at: https://www.gov.uk/government/uploads/system/uploads/attac hment_data/file/633270/air-quality-plan-detail.pdf

Department for Environment, Food \& Rural Affairs (2019) Clean Air Strategy. Available at: https://assets.publishing.service.gov. uk/government/uploads/system/uploads/attachment_data/file/ 770715/clean-air-strategy-2019.pdf

Engström E, Forsberg B (2019) Health impacts of active commuters' exposure to traffic-related air pollution in Stockholm, Sweden. Journal of Transport \& Health 14:100601

Ezratty V, Guillossou G, Neukirch C et al (2014) Repeated nitrogen dioxide exposures and eosinophilic airway inflammation in asthmatics: a randomized crossover study. Environ Health Perspect 122:850-856

Girman JR (1992) Comment on the use of plants as a means to control indoor air pollution. In: EPA (United States Environ. Prot. Agency) - NSCEP (National Serv Cent Environ Publ). https:// nepis.epa.gov/Exe/ZyNET.exe/000002IB.TXT?ZyActionD= ZyDocument $\&$ Client $=$ EPA\&Index $=1991+$ Thru+1994\&Docs $=$ $\&$ Query $=\&$ Time $=\&$ EndTime $=\&$ SearchMethod $=1 \&$ TocRe strict $=$ n $\&$ Toc $=\&$ TocEntry $=\& Q$ Field $=\& Q$ Field Year $=\& Q$ Fiel
$\mathrm{dMonth}=\& \mathrm{QFieldDay}=\&$ IntQFieldOp $=0 \&$ ExtQFieldOp $=0 \&$ XmlQuery=\&File=D\%3A\%5Czyfiles\%5CIndex\%20Data\%5C $91 \mathrm{t}$ hru94\%5CTxt\%5C00000002\%5C000002IB.txt\&User=ANONY MOUS\&Password=anonymous\&SortMethod $=\mathrm{h} \% 7 \mathrm{C} \&$ Maxim umDocuments $=1 \&$ Fuzzy Degree $=0 \&$ Image Quality $=r 75 \mathrm{~g} 8 /$ r75g8/x150y 150g 16/i425\&Display $=$ hpfr \&DefSeekPage $=x \&$ SearchBack $=$ ZyActionL\&Back $=$ ZyActionS $\&$ BackDesc $=$ Resul ts $\% 20$ page $\&$ MaximumPages $=1 \&$ ZyEntry $=1 \&$ SeekPage $=\mathrm{x} \&$ ZyPURL. Accessed June 17, 2021

Gourdji S (2018) Review of plants to mitigate particulate matter, ozone as well as nitrogen dioxide air pollutants and applicable recommendations for green roofs in Montreal, Quebec. Environ Pollut 241:378-387

Gubb C, Blanusa T, Griffiths A, Pfrang C (2018) Can houseplants improve indoor air quality by removing $\mathrm{CO}_{2}$ and increasing relative humidity? Air Qual Atmos Health 11:1191-1201

Gubb C, Blanusa T, Griffiths A, Pfrang C (2019) Interaction between plant species and substrate type in the removal of $\mathrm{CO}_{2}$ indoors. Air Qual Atmos Health 12:1197-1206

Gubb C, Blanusa T, Griffiths A, Pfrang C (2020) Can plants be considered a building service? Build Serv Eng Res T 41:374-384

Guerriero C, Chatzidiakou L, Cairns J, Mumovic D (2016) The economic benefits of reducing the levels of nitrogen dioxide $\left(\mathrm{NO}_{2}\right)$ near primary schools: the case of London. J Environ Manage 181:615-622

Hasselblad V, Eddy DM, Kotchmar DJ (1992) Synthesis of environmental evidence - nitrogen dioxide epidemiology studies. J Air Waste Manage 42:662-671

HM-Government (2015) Ventilation: approved document F. 60. Available at: https://assets.publishing.service.gov.uk/gover nment/uploads/system/uploads/attacment_data/file/468871/ ADF_LOCKED.pdf

$\mathrm{Hu}$ Y, Sun G (2010) Leaf nitrogen dioxide uptake coupling apoplastic chemistry, carbon/sulfur assimilation, and plant nitrogen status. Plant Cell Rep 29:1069-1077

Irga PJ, Pettit TJ, Torpy FR (2018) The phytoremediation of indoor air pollution: a review on the technology development from the potted plant through to functional green wall biofilters. Rev Environ Sci Biotechnol 17:395-415

Janssen NAH, van Vliet PHN, Aarts F, Harssema H, Brunekreef B (2001) Assessment of exposure to traffic related air pollution of children attending schools near motorways. Atmos Environ 35:3875-3884

Jim CY, Chen WY (2008) Assessing the ecosystem service of air pollutant removal by urban trees in Guangzhou (China). J Environ Manage 88:665-676

Kattan M, Gergen PJ, Eggleston P, Visness CM, Mitchell HE (2007) Health effects of indoor nitrogen dioxide and passive smoking on urban asthmatic children. J Allergy Clin Immun 120:618-624

Kim KJ, Khalekuzzaman M, Suh JN et al (2018) Phytoremediation of volatile organic compounds by indoor plants: a review. Hortic Environ Biotechnol 59:143-157

Kodama Y, Arashidani K, Tokui $\mathrm{N}$ et al (2002) Environmental $\mathrm{NO}_{2}$ concentration and exposure in daily life along main roads in Tokyo. Environ Res 89:236-244

Koistinen K, Kotzias D, Kephalopoulos S et al (2008) The INDEX project: executive summary of a European Union project on indoor air pollutants. Allergy 63:810-819

Malley C, Moller S, Braban C, Hicks W, Heal M (2018) Analysis of the distributions of hourly $\mathrm{NO}_{2}$ concentrations contributing to annual average $\mathrm{NO}_{2}$ concentrations across the European monitoring network between 2000 and 2014. Atmos Chem Phys 18:3563-3587

Morikawa H, Higaki A, Nohno M et al (1998) More than a 600-fold variation in nitrogen dioxide assimilation among 217 plant taxa. Plant Cell Environ 21:180-190 
Nakai S, Nitta H, Maeda K (1995) Respiratory health associated with exposure to automobile exhaust. II. Personal NO2 exposure levels according to distance from roadside. J Expo Anal Environ Epidemiol 5:125-136

Niimi A, Matsumoto H, Takemura M et al (2003) Relationship of airway wall thickness to airway sensitivity and airway reactivity in asthma. Am J Respir Crit Care 186:983-989

Nowak DJ, Hirabayashi S, Bodine A, Greenfield E (2014) Tree and forest effects on air quality and human health in the United States. Environ Pollut 193:119-129

Paulin LM, Diette GB, Scott M, McCormack MC, Matsui EC, CurtinBrosnan J, Williams DL, Kidd-Taylor A, Shea M, Breysse PN, Hansel NN (2014) Home interventions are effective at decreasing indoor nitrogen dioxide concentrations. Indoor Air 24(4):416-24. https://doi.org/10.1111/ina.12085

Pettit T, Irga PJ, Surawski NC, Torpy FR (2019) An assessment of the suitability of active green walls for $\mathrm{NO}_{2}$ reduction in green buildings using a closed-loop flow reactor. Atmosphere 10(12):801

Pettit T, Irga PJ, Torpy FR (2020) The botanical biofiltration of elevated air pollution concentrations associated the Black Summer wildfire natural disaster. J Hazard Mater Lett 1:100003. https:// doi.org/10.1016/j.hazl.2020.100003

Pettit T, Torpy FR, Surawski NC, Fleck R, Irga PJ (2021) Effective reduction of roadside air pollution with botanical biofiltration. J Hazard Mater 414:125566. https://doi.org/10.1016/j.jhazmat. 2021.125566

Strand V, Svartengren M, Rak S, Barck C, Bylin G (1998) Repeated exposure to an ambient level of $\mathrm{NO}_{2}$ enhances asthmatic response to a nonsymptomatic allergen dose. Eur Respir J 12:6-12
Teklemariam TA, Sparks JP (2006) Leaf fluxes of $\mathrm{NO}$ and $\mathrm{NO}_{2}$ in four herbaceous plant species: the role of ascorbic acid. Atmos Environ 40(12):2235-2244

Torpy F, Clements N, Pollinger M et al (2018) Testing the single-pass VOC removal efficiency of an active green wall using methyl ethyl ketone (MEK). Air Qual Atmos Health 11:163-170

Tunnicliffe WS (1994) Effect of domestic concentrations of nitrogen dioxide on airway responses to inhaled allergen in. Lancet 344:1733-1737

Vallano DM, Sparks JP (2008) Quantifying foliar uptake of gaseous nitrogen dioxide using enriched foliar $\delta 15 \mathrm{~N}$ values. New Phytol 177:946-955

Vaz Monteiro M, Blanusa T, Verhoef A, Hadley P, Cameron RWF (2016) Relative importance of transpiration rate and leaf morphological traits for the regulation of leaf temperature. Aust J Bot 64:32-44

World Health Organisation (2010) WHO guidelines for indoor air quality: selected pollutants. ISBN: 9789289002134. Available at: https://www.who.int/publications/i/item/9789289002134

Zhang H, Pennisi SV, Kays SJ, Habteselassie MY (2013) Isolation and identification of toluene-metabolizing bacteria from rhizospheres of two indoor plants. Water Air Soil Pollut 224(9):1-14

Publisher's note Springer Nature remains neutral with regard to jurisdictional claims in published maps and institutional affiliations. 